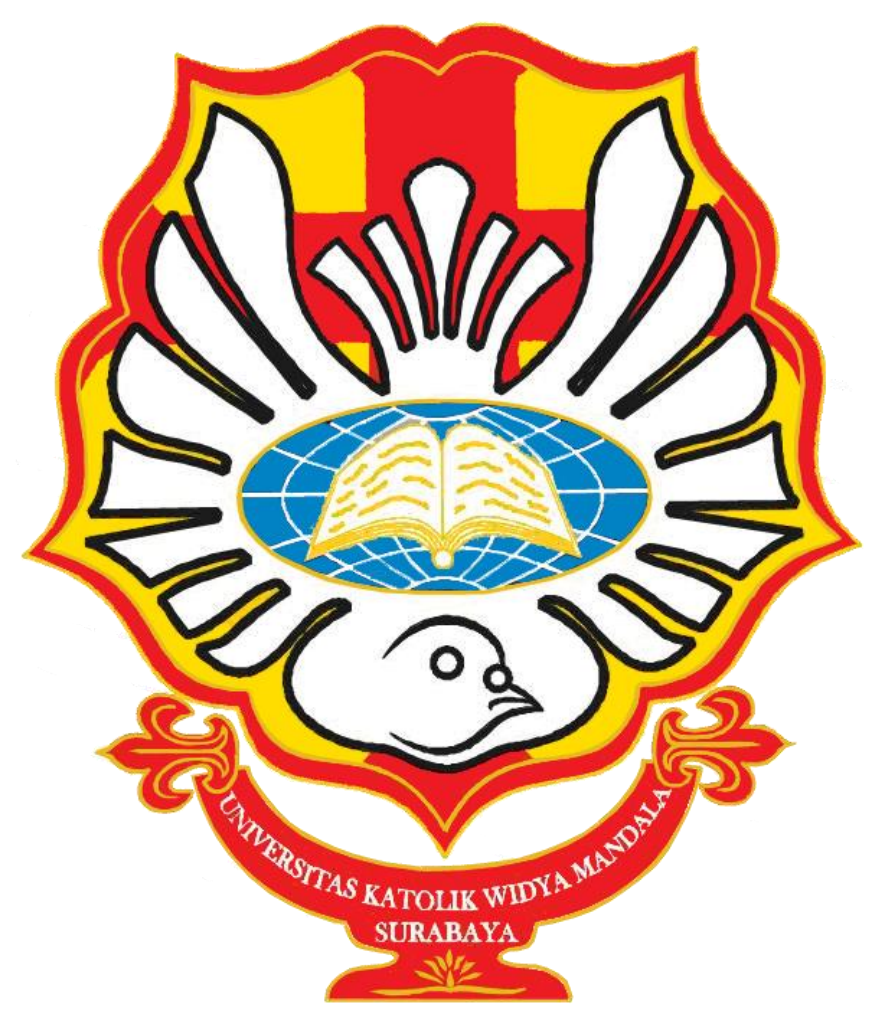

Disusun oleh:

Panji Andy Satriabuana (41417010)

FAKULTAS TEKNIK

PROGRAM STUDI TEKNIK INDUSTRI

UNIVERSITAS KATOLIK WIDYA MANDALA SURABAYA KAMPUS MADIUN 


\title{
KASUS PEMBUNUHAN SEORANG IBU MUDA DI NGAWI DALAM SUDUT PANDANG FILSAFAT MANUSIA
}

\author{
Oleh: \\ Panji Andy Satriabuana \\ Universitas Widya Mandala Surabaya Kampus Madiun
}

\begin{abstract}
ABSTRAK
Kejahatan pada saat ini banyak melibatkan remaja atau generasi muda atau yang lainnya yang menjadi pelaku. Kejahatan yang sedang terjadi adalah kejahatan pembunuhan yang dilakukan oleh pelaku terhadap mantan kekasihnya. Permasalahan dalam penelitian ini adalah: 1. Apakah faktor pemicu yang menyebabkan terjadinya pembunuhan terhadap ibu muda dan anaknya oleh mantan kekasihnya. 2. Bagaimana upaya penanggulangan kejahatan pembunuhan terhadap ibu muda dan anaknya oleh mantan kekasihnya. Penelitian ini dilakukan menggunakan pendekatan teori manusia: 1. Filsafat sebagai proses berfikir. 2 . Intelek dan kehendak manusia. Berdasarkan hasil penelitian dan pembahasan dapat disimpulkan: 1. Faktor-faktor penyebab pelaku melakukan kejahatan pembunuhan terhadap mantan kekasihnya bersumber dari faktor internal yaitu faktor emosional, faktor psikologis, dan faktor eksternal yaitu faktor agama, faktor keluarga dan faktor lingkungan. 2. Upaya penanggulangan yang dilakukan terhadap kejahatan pembunuhan pelaku terhadap mantan kekasihnya dilakukan secara dengan bersifat mencegan dan menahan. Pihak kepolisian mengadakan penyuluhan dan sosialisasi tentang jenis pidana atau kejahatan berikut sanksinya, serta menegakkan hukum secara tegas dan sesuai dengan peraturan yang sudah dibuat oleh pemerintah agar membuat efek jera kepada pelaku.
\end{abstract}

Kata kunci: Analisis Krimonoligis, pembunuhan pelaku terhadap mantan kekasih, filsafat manusia 


\section{PENDAHULUAN}

\subsection{Latar Belakang}

Evolusi budaya atau adat yang dilangsir sebagai proses modernisasi, meruypakan perubahan yang umum dalam terjadi pada sebuah negara, dan Indonesia merupakan negara yang berkembang dalam proses modernisasi. Secara tidak langsung akan membuat perubahan dalam segala hal, antara lain adat, budaya dan pola pikir masyarakat. Hal ini akan menimbulkan dampak positif dan negatif. Dampak negatrif yang menarik masyarakat adalah terjadinya kriminalitas atau kejahatan yang melibatkan generasi muda dan orang lain menjadi pelaku, seperti kejahatan pembunuhan yang dilakukan oleh mantan kekasih dan yang banyak menjadi korban adalah wanita/ibu muda dan juga melukai anaknya ibu muda tersebut. Faktor utama pemicu pembunuhan adalah konfil sosio-emosional, karena seseorang merasa kecewa, sakit hati atau dendam kepada orang lain. Secara ekstrim pelampiasan rasa kecewa tersebut, sakit hati, dendam atau amarah dilampiaskan dengan cara membunuh orang lain. Hal ini yang sedang banyak terjadi pada kasus-kasus pembunuhan di masyarakat.

Upaya penanggulangan atau mengatasi agar seseorang tidak melakukan kasus kejahatan pembunuhan terhadap orang lain diperlukan bimbingan dan pendidikan moral, pendidikan norma agama dan bermasyarakat. Sehingga untuk melakukan yang bertentangan dengan agama dan bertentangan dengan undang-undang akan jauh dari pikirannya untuk melakukan perbuatan kejahatan pembunuhan tersebut. Perbuatan kejahatan pembunuhan yang tidak layak untuk dilakukan oleh seseorang begitu mudahnya dilakukan tanpa adanya pemikiran kedepannya. Pada kasus pembunuhan yang terjadi adalah pembunuhan seorang ibu di Dusun Jatisari, Desa Karangbanyu, Kecamatan Widodaren, Ngawi, ditemukan bersimbah darah di rumahnya. Kondisinya mengenaskan dengan luka bacok di tubuhnya. Korban wanita tersebut adalah Susanti (30). Ibu dua anak itu ditemukan pertama kali oleh mertuanya, Katijan (54) dan adik iparnya, Rumini (25) pada senin (25/3/19) sekitar pukul 23.50 
WIB. Keduanya lalu membawa korban ke puskesmas terdekat dan akhirnya dirujuk ke RSUD dr Soeroto Ngawi."Korban meninggal di RSUD dr Soeroto Ngawi pukul 02.00 WIB karena pendarahan banyak di kepala," kata Kasat Reskrim Polres Ngawi AKP Indra Najib.

\subsection{Rumusan Masalah}

1. Apakah faktor pemicu yang menyebabkan terjadinya pembunuhan terhadap ibu muda dan anaknya oleh mantan kekasihnya ?

2. Bagaimana upaya penanggulangan kejahatan pembunuhan terhadap ibu muda dan anaknya oleh mantan kekasihnya?

\subsection{Tujuan Masalah}

1. Memberikan upaya penanggulangan atau mengatasi agar seseorang tidak melakukan kejahatan terhadap orang lain maupun mantan kekasihnya.

\section{PEMBAHASAN}

\section{A. Faktor pemicu yang menyebabkan terjadinya pembunuhan terhadap} ibu muda dan anaknya oleh mantan kekasihnya dan hubungan dengan Filsafat Manusia.

Kejahatan merupakan suatu hal yang sudah tidak asing lagi, pada saat ini kejahatan sering terjadi di masyarakat. Kejahatan dapat dilakukan oleh siapapun, dimanapun, kapanpun. Kejahatan pula dapat dilakukan oleh usur tidak sengaja maupun sengaja, seperti yang dilakukan oleh mantan kekasih Susanti ini dilakukan karena kecewa, sakit hati terhadap Susanti dulunya. 


\section{TEORI}

\section{FILSAFAT SEBAGAI PROSES BERFIKIR}

Teori tentang Filsafat Manusia menyebutkan Filsafat Manusia (filsafat antropologi) adalah filsafat integral dan mendalam tentang manusia. Tidak hanya secara biologis, atau psikologis. Filsafat manusia lebih bernuansa metafisis. Manusia adalah makhluk yang senantiasa berfikir. Dengan berfikir inilah, pada awalnya manusia merasa heran dengan segala sesuatu yang ada dan yang terjadi di alam semesta, hingga akhirnya dengan kemampuan berfikir inilah yang mengantar manusia untuk memperoleh suatu jawaban yang bersifat logis. Proses berfilsafat adalah proses berfikir, tetapi tidak semua proses berfikir adalah proses berfilafat. Berfikir yang bagaimana dapat dikatakan berfilsafat? Berfilsafat adalah berfikir yang radikal, logis, inuversal, konseptual, koheren, konsisten, sistematik, komperehensif, kritis, bebas, bertanggung jawab, dan bijaksana. Filsafat ditujukan untuk mendapatkan kebenaran mutlak (absolut) yaitu benar dilihat dari berbagai sudut pandang dan benar pula untuk sepanjang masa. Artinya, filsafat mamandang segala sesuatu secara komprehensif.

Filsafat membantu manusia untuk mecari kebenaran dari segala fenomena yang ada, memberikan pengertian tentang cara hidup, pamdangan hidup dan pandangan dunia, memberikan ajaran tentang moral dan etika yang berguna dalam kehidupan memahami diri sendiri dan dunia, mengembangkan kemampuan dalam menalar, dan memberikan bekal untuk memperhatikan pandangan diri sendiri dan orang lain dengan kritis. Lebih jauh dari itu filsafat memberikan pandangan yang luas sehingga manusia dapat membendung egoisme dan ego-sentrisme, membebaskan manusia dari belenggu cara berfikir yang sempit, memberikan landasan historisfilosofis bagi setiap kajian disiplin ilmu yang ditekuni, memberikan nilai dan orientasi yang jelas bagi setiap disiplin ilmu. Fakta yang ada dalam diri manusia: manusia bisa berfikir dan bertanya, juga tentang dirinya sendiri. Semakin hari ia semakin mempertanyakan dirinya sendiri, dan makin merasa tidak pasti. 
Dari kasus kejahatan pembunuhan diatas tidak sama sekali berfikir secara filsafat, adapun 2 faktor yang mempengaruhi kasuk kejahatan pembunuhan tersebut, yaitu :

\section{Faktor Internal}

Faktor internal adalah faktor-faktor yang terdapat pada individu. Faktor-faktor internal penyebab terjadinya kejahatan pembunuhan Susanti oleh mantan kekasihnya yaitu faktor pemikiran,emosional, faktor psikologis.

\section{Faktor Eksternal}

Faktor eksternal adalah faktor-faktor yang terdapat dari luar diri individu, seperti faktor agama, faktor tontonan atau bacaan serta faktor keluarga dan lingkungan. Faktor penyebab terhadap kasus pembunuhan Susanti oleh mantan kekasihnya yaitu daya emosional yang ditimbulkan dari perasaan sakit hati dan cemburu. Faktor tontonan yang memotivasi pelaku untuk melakukan kejahatan pembunuhan tersebut. Faktor pembunuhan Susanti oleh mantan kekasihnya tersebut adalah faktor emosional dari si pelaku untuk melakukan pembunuhan tersebut. Faktor agama yang rendah sehingga memiliki dampak bagi pelaku untuk melakukan suatu kejahatan dengan mudah. Faktor lingkungan dan keluarga juga mempengaruhi seseorang dalam melakukan kejahatan, karena keluarga dan lingkungan yang buruk akan memberikan dampak yang buruk bagi perilaku seseorang. Pada kasus diatas mampunyai faktor yaitu faktor emosional yang tidak terkontrol karena kecewa dan sakit hati kepada Susanti sehingga ia membunuh susanti hingga melukai anak dari Susanti. Juga faktor psikologis juga dapat mempengaruhi si pelaku tersebut untuk melakukan kejahatan pembunuhan terhadap Susanti, karena berdasarkan masalah-masalah dan tekanan-tekanan yang mendorong pelaku melakukan pembunuhan 
terhadap Susanti, ia melakukan kejahatan pembunuhan atas dasar cemburu dan sakit hati terhadap Susanti.

\section{B. Upaya penanggulangan kejahatan pembunuhan terhadap ibu muda dan anaknya oleh mantan kekasihnya dan hubungan dengan filsafat manusia.}

Upaya penanggulangan kejahatan secara garis besar dapat dibagi dua, yaitu lewat jalur "penal" (hukum pidana) dan lewat jalur "nonpenal" (bukan/ diluar hukum pidana), upaya penanggulangan kejahatan dapat ditempuh dengan:
a. Penerapan hukum pidana.
b. Pencegahan tanpa pidana.
c. Memengaruhi pandangan masyarakat mengenai kejahatan.

\section{Sarana Non Penal}

Sarana non penal yaitu dengan upaya bersifat mencegah dengan melakukan pencegahan sebelum kejahatan itu terjadi. Salah satu jalur non-penal untuk mengatasi masalah-masalah sosial yaitu dengan jalur kebijakan sosial. Kebijakan sosial pada dasarnya adalah kebijakan atau upaya-upaya rasional untuk mencapai kesejahteraan masyarakat. Mengenai upaya penanggulangan kejahatan pembunuhan Susanti oleh mantan kekasihnya, yaitu:

1. Peningkatan pengetahuan agama pada setiap individu sangat diperlukan agar terhindar dari perbuatan yang menyimpang dari norma agama maupun peraturan.

2. Pemerintah dapat menyaring atau menyeleksi tontonan, berita yang pantas dan layak untuk ditayangkan, ada kemungkinan dari tayangan di televisi yang memotivasi seseorang untuk melawan tindakan melawan hukum. 
3. Keluarga dapat menanamkan nilai-nilai moral dan agama kepada seluruh anggotanya serta mengontrol perilaku sosial yang berkembang di masyarakat.

\section{Sarana Penal}

Sarana penal merupakan sarana atau upaya yang bersifat represif yaitu dilakukan setelah kejahatan terjadi dengan menggunakan Hukum pidana, berupa penegakan hukum dengan menjatuhkan hukuman dan berjutuan untuk efek jera agar tidak terjadinya kejahatan tersebut dan mamasyarakatkan pelaku agar diterima kembali di dalam masyarakat dengan sejahtera.

\section{INTELEK DAN KEHENDAK MANUSIA}

Manusia di satu pihak mempunyai kebebasan, tetapi di lain pihak juga tergantung. Ketika memutuskan, manusia bebas, tetapi setelah itu ia harus tunduk pada apa yang sudah diputuskan. Aliran determinisme mengatakan bahwa manusia itu tidak bebas dan ditentukan oleh unsurunsur lain (Hegel: dialektika Roh, Spinoza: substansi mutlak penentu segala sesuatu, dan Carl Gustav Jung: manusia bergantung pada hukum yang ada), sedangkan aliran indeterminisme mengatakan bahwa manusia itu bebas mutlak (Fichte: menusia menentukan dirinya sendiri, Atomistis: semua adalah peristiwa atom yang terjadi secara kebetulan). Konflik dalam memahami kebebasan terjadi antara paham determinisme dan indeterminisme. Jadi hakekat manusia adalah suatu keharusan (manusia menerima suatu keniscayaan kodrati), suatu kebebasan (manusia itu otonom dan unik). Keharusan dan kebebasan ini ada dalam satu kesatuan substansial. Dengan kata lain, manusia itu kebebasan yang mengharuskan, dan keharusan yang membebaskan. Di dalam kebebasan termuat keharusan, dan di dalam keharusan termuat kebebasan. 


\section{KESIMPULAN}

Berdasarkan hasil dari penelitian dan pembahasan mengenai kasus kejahatan pembunuhan Susanti oleh mantan kekasihnya, dapat ditarik simpulan bahwa:

1. Faktor penyebab terjadinya kejahatan pembunuhan Susanti oleh mantan kekasihnya yaitu faktor internal yang timbul dari diri pelaku seperti faktor daya emosional, faktor psikologis, dan faktor eksternal yaitu dari luar diri pelaku seperti faktor agama, faktor lingkungan, dan faktor keluarga. Sebab kejahatan selain faktor internal dan eksternal juga dapat dikategorikan berdasarkan teori filsafat manusia, pelaku tidak berfikir radikal, logis, inuversal, konseptual, koheren, konsisten, sistematik, komperehensif, kritis, bebas, bertanggung jawab, dan bijaksana. Sehingga melakukan perbuatan yang melawan hukum.

2. upaya penanggulangan kejahatan pembunuhan terhadap ibu muda dan anaknya oleh mantan kekasihnya, yaitu:

a. Pihak kepolisian melakukan upaya bersifat mencegah dengan mengadakan sosialisasi atau penyuluhan hukum mengenai jenis tindak pidana atau kejahatan serta akibat-akibat hukum yang akan timbul jika melakukan kejahatan khususnya kejahatan pembunuhan mantan kekasihnya atau pembunuhan model lainnya. Serta melakukan upaya menahan pelaku apabila telah terjadi kejahatan pembunuhan dengan meneggakkan hukum secara tegas dan sesuai peraturan yang sudah dibuat agar membuat efek jera kepada pelaku.

b. Pihak lembaga permasyarakatan melakukan pembinaan kepada narapidana yaitu pembinaan keterampilan, pembinaan agama, pembinaan rohani serta jasmani dengan tujuan utama untuk megembalikan keadaan dan kondisi narapidana lebih baik sehingga dengan harapan dapat diterima kembali oleh lingkungan sekitar atau masyarakat, dapat melanjutkan hidupnya dengan keluarganya dan tidak ada fikiran untuk mengulang kejahatan pembunuhan yang kedua kalinya. 


\section{DAFTAR PUSTAKA}

Dewantara, A. W, Diktat Filsafat Manusia Tentang Intelek, Kehendak, Dan Dinamika Manusia.2019

https://news.detik.com/berita-jawa-timur/d-4485006/tragedi-dini-hari-di-ngawiibu-muda-diduga-dibunuh-selingkuhan 